\title{
Clinical course of primary HIV infection: consequences for subsequent course of infection
}

Court Pedersen, Bjarne Ørskov Lindhardt, Birgitte Løkke Jensen, Edgar Lauritzen, Jan Gerstoft, Ebbe Dickmeiss, Johannes Gaub, Elma Scheibel, Tonny Karlsmark

Abstract

Objective-To investigate the impact of the clinical course of the primary HIV infection on the subsequent course of the infection.

Design-Prospective documenting of seroconversion, follow up at six month intervals, and analysis of disease progression by life tables.

Patients-86 Men in whom seroconversion occurred within 12 months.

Primary outcome measure-Progression of HIV infection, defined as CD4 lymphocyte count $<0.5 \times 10^{9} / 1$, recurrence of $\mathrm{HIV}$ antigenaemia, or progression to Centers for Disease Control group IV.

Main results-Median follow up was 670 (range 45-1506) days. An acute illness like glandular fever occurred in $46(53 \%)$ subjects. Three year progression rates to Centers for Disease Control group IV was $78 \%$ at three years for those who had longlasting illnesses (duration $\geqslant 14$ days) during seroconversion as compared with $10 \%$ for those who were free of symptoms or had mild illness. All six patients who developed AIDS had had longlasting primary illnesses. Three year progression rates to a CD4 lymphocyte count $<0.5 \times 10^{9} / 1$ and to recurrence of HIV antigenaemia were significantly higher for those who had longlasting primary illnesses than those who had no symptoms or mild illness $(75 \% v 42 \%$ and $55 \% v 14 \%$, respectively).

Conclusion-The course of primary infection may determine the subsequent course of the infection.

and Venereology

Bispebjerg Hospital,

Copenhagen

Birgitte Løkke Jensen, MD, registrar

AIDS Laboratory, Statens Seruminstitut, Copenhagen Edgar Lauritzen, MD, registrar

Tissue Typing Laboratory, Rigshospitalet,

Copenhagen

Ebbe Dickmeiss, MD, registrar

Department of Paediatrics, Rigshospitalet,

Copenhagen

Elma Scheibel, MD, registrar

Department of

Dermatology and

Venereology,

Rigshospitalet,

Copenhagen

Tonny Karlsmark, MD, registrar

Correspondence and requests for reprints to: $\mathrm{Dr}$ Pedersen. heterosexuals. The median age was 30 (range 14-59) years.

Seroconversion was documented prospectively through repetitive HIV testing at the screening clinics in the period November 1984 to August $1988 .{ }^{8}$ Everyone had a physical examination and was given a standardised questionnaire by an interviewer that sought information on illnesses within the previous three months. ${ }^{9}$ The result of the antibody test was not known at the time of the interview. The study group made up about $15 \%$ of all subjects positive for HIV followed at the Copenhagen AIDS screening clinics; it included all known to have become seropositive within 12 months.

The date of seroconversion was calculated as the midpoint of the dates of the last test result negative for HIV and the first confirmed positive result or, when possible, taken as the date of the serum sample positive for HIV antigen and negative for HIV antibody or the sample positive for $\mathrm{p} 24$ antibody and negative for HIV antibody on enzyme linked immunosorbent assay (ELISA). The median interval between the last negative and the first positive test for HIV antibody was 108 (range 6-392) days. For one subject the interval exceeded 12 months, but a serum sample positive for HIV antigen was available from the intervening period. Three patients became positive for HIV antibody in 1984, 35 in 1985, 22 in 1986, 18 in 1987, and eight in 1988.

Antibody to HIV was determined by ELISA and serum samples were confirmed as positive by an immunoblot method. ${ }^{10}$ When available, stored serum samples were tested for HIV antigen. ${ }^{11}$ All subjects had serological tests for syphilis, cytomegalovirus infection, and hepatitis $B$. T cell subsets were determined about every six months with monoclonal antibodies. $^{5}$

During follow up the subjects were seen about every six months. At each visit they were interviewed about symptoms related to infection with HIV and given a physical examination.

Disease was classified according to the Centers for Disease Control classification system for HIV infection, ${ }^{12}$ and AIDS was defined according to the Centers for Disease Control revised surveillance definition. ${ }^{13}$ Generalised lymphadenopathy was defined as the presence of lymph nodes with a diameter $>1 \mathrm{~cm}$ at two or more extrainguinal sites. Clinical signs of immune deficiency during the acute HIV infection (oral thrush, oesophageal candidiasis, or herpes zoster) were regarded as part of the acute illness (Centers for Disease Control group I).

A primary illness was defined as an acute onset febrile illness lasting for at least three days in association with seroconversion. A longlasting illness was arbitrarily defined as an illness with fever lasting 14 days or more. The following were chosen as criteria of progression of HIV infection: CD4 lymphocyte count $<0.5 \times 10^{9} / 1$, recurrence of HIV antigenaemia, or progression to Centers for Disease Control group IV.

Life tables were used to analyse progression, in- 
cluding progression to a CD4 lymphocyte count $<0.5 \times 10^{9} / 1$ and recurrence of HIV antigenaemia, and were compared by the log rank test. ${ }^{14}$ Within subject changes in CD4 lymphocyte counts were analysed by the Wilcoxon one sample rank sum test. All significance levels correspond to those for two tailed tests.

\section{Results}

Median follow up from estimated date of seroconversion was 670 (range 45-1506) days. Eight (9\%) of the 86 subjects were lost to follow up a median of 269 (range 47-833) days after the estimated date of seroconversion.

\section{ACUTE CLINICAL ILLNESS}

Forty six $(53 \%)$ subjects had an acute clinical illness associated with seroconversion, and of these 27 had a longlasting primary illness. The symptoms and clinical signs are presented in table I. The median duration

TABLE I-Clinical signs and symptoms associated with primary HIV infection in 86 men who became positive for HIV antibody

\begin{tabular}{|c|c|c|}
\hline & $\begin{array}{c}\text { No (\%) } \\
\text { with symptom }\end{array}$ & $\begin{array}{l}\text { Median (range) } \\
\text { duration of } \\
\text { symptom (days) }\end{array}$ \\
\hline No primary illness & $40(47)$ & \\
\hline Primary illness & $46(53)$ & $16(4-56)$ \\
\hline Fever & $46(53)$ & $16(4-56)$ \\
\hline Generalised lymphadenopathy & $36(42)$ & \\
\hline Trunk rash & $21(24)$ & $9(5-40)$ \\
\hline Sore throat & $31(36)$ & $10(4-32)$ \\
\hline Oral thrush & $9(10)$ & $14(7-30)$ \\
\hline Dry cough & $19(22)$ & $8(3-14)$ \\
\hline Arthralgia or myalgia & $16(19)$ & $14(3-28)$ \\
\hline Weight loss & $11(13)$ & $21(14-30)$ \\
\hline Diarrhoea & $9(10)$ & $7(2-21)$ \\
\hline Encephalitis & $4(5)$ & $10(3-21)$ \\
\hline Oesophageal candidiasis & $2(2)$ & \\
\hline Herpes zoster & $1(1)$ & \\
\hline Glomerulonephritis & $1(1)$ & \\
\hline $\begin{array}{l}\text { Pneumonitis } \\
\text { Pand }\end{array}$ & $2(1)$ & -. \\
\hline Anal ulceration & $1(1)$ & \\
\hline
\end{tabular}

of acute illness was 16 (range 4-56) days. Twenty two $(44 \%)$ of 50 subjects who were examined for HIV antigen at seroconversion were temporarily positive for HIV antigen. There was no significant difference between subjects with longlasting primary illnesses and those with mild illness or no symptoms in regard to HIV antigenaemia at seroconversion $(50 \%$ and $41 \%$ respectively). No subject had serological evidence of syphilis, recent infection with hepatitis B virus, or cytomegalovirus.

CHANGES IN T CELL SUBSETS AND RECURRENCE OF HIV ANTIGENAEMIA

$\mathrm{T}$ cell subset counts were available for 84 subjects. Of these, $17(20 \% ; 95 \%$ confidence interval $11 \%$ to $35 \%$ ) had progressed to a CD4 lymphocyte count $<0.5 \times 10^{9} / 1$ at one year, $29(35 \% ; 22 \%$ to $48 \%)$ at two years, and $47(56 \% ; 35 \%$ to $77 \%)$ at three years. Stored serum samples collected during follow up were available from 70 subjects, and HIV antigenaemia recurred in five $(7 \% ; 0 \%$ to $13 \%)$ at one year, $14(20 \% ; 8 \%$ to $32 \%)$ at two years, and $18(26 \% ; 9 \%$ to $44 \%)$ at three years. Both recurrence of HIV antigenaemia and progression to CD4 lymphocyte count $<0.5 \times 10^{9} / 1$ were significantly associated with a longlasting primary illness (table II).

We also compared changes in the absolute number of CD4 lymphocytes after seroconversion (fig 1). At baseline and at six month follow up there was no significant difference in the CD4 cell count between the groups, but during the second year after seroconversion the CD4 cell count decreased significantly in the group with longlasting illness in association with seroconversion whereas it remained stable in those
TABLE II - Progression to CD4 lymphocyte count $<0 \cdot 5 \times 10^{\%} / l$ and recurrence of HIV antigenaemia related to clinical course of primary infection

\begin{tabular}{lcc}
\hline $\begin{array}{l}\text { Duration of primary illness } \\
\text { (days) }\end{array}$ & $\begin{array}{c}\text { Three year progression } \\
(95 \% \text { confidence interval })\end{array}$ & Significance \\
\hline & CD4 lymphocyte count $<0.5 \times 10^{\%} / 1$ \\
$75 \%(45 \%$ to $100 \%)$ & \\
$\geqslant 14$ days $(\mathrm{n}=26)$ & $42 \%(23 \%$ to $73 \%)$ & $\mathrm{p}=0.009$ \\
$<14$ days $(\mathrm{n}=58)$ & Recurrence of HIV antigenaemia & \\
& $55 \%(25 \%$ to $84 \%)$ & \\
$\geqslant 14$ days $(\mathrm{n}=24)$ & $14 \%(0 \%$ to $31 \%)$ & $\mathrm{p}=0.036$ \\
$<14$ days $(\mathrm{n}=46)$ & &
\end{tabular}

^Analysed by life tables.

†Log rank test.

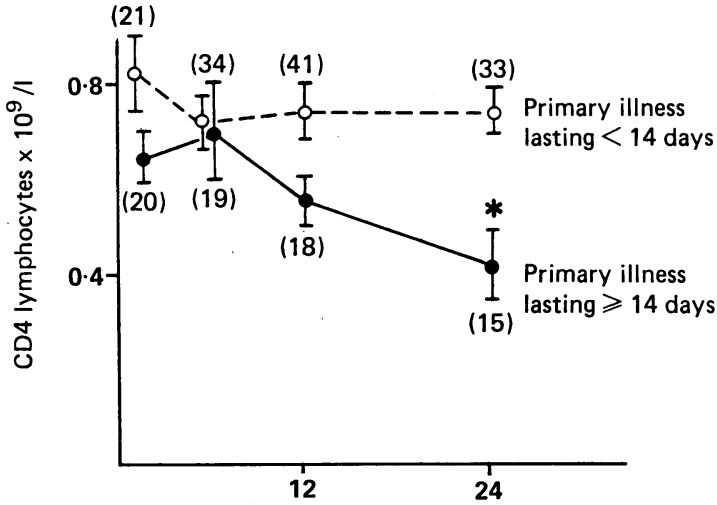

Time after seroconversion (months)

FIG 1-Changes in CD4 lymphocyte count during 24 months of follow up related to clinical course of primary infection. Bars show mean and standard error; number of analyses is shown in parentheses. Asterisk indicates significant difference compared with baseline values $(p<0.05)$

who had mild illness or no symptoms during seroconversion.

DISEASE PROGRESSION TO CENTERS FOR DISEASE CONTROL GROUP IV

Eighteen $(21 \%)$ of the patients progressed to Centers for Disease Control group IV. Disease was manifested by constitutional symptoms in two patients, minor opportunistic infections in 11 (seven with oral thrush, one with hairy leucoplakia, three with herpes zoster), and AIDS associated opportunistic infections in five (four with Pneumocystis carinii pneumonia, one with oesophageal candidiasis). The overall actuarial progression rate to group IV was 35\% (95\% confidence interval $13 \%$ to $58 \%$ ) at three years.

Disease progression was significantly associated with the duration of symptoms during seroconversion $(\mathrm{p}<0.001)$ (fig 2$)$. The three year progression rate was $78 \%(52 \%$ to $100 \%)$ for subjects with longlasting

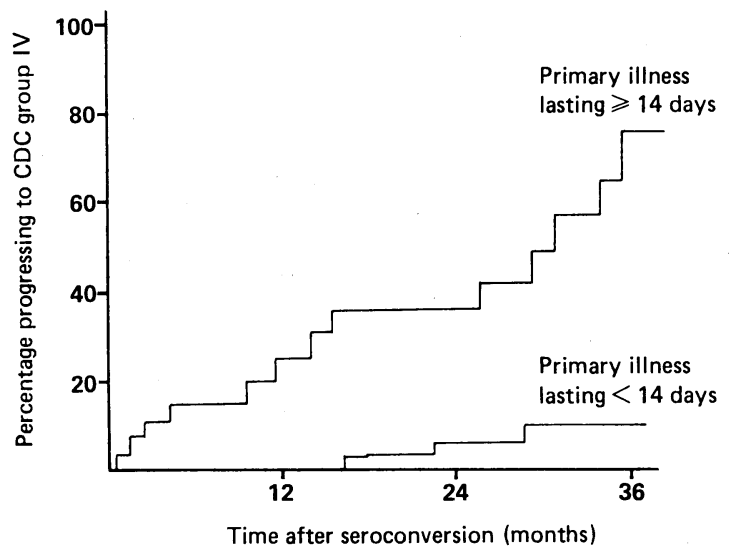

FIG 2-Progression to Centers for Disease Control group IV in 86 men who became positive for HIV antibody related to clinical course of primary infection. Life tables were used to analyse disease progression and were compared by log rank test 
primary illnesses compared with $10 \%(0 \%$ to $28 \%)$ for those who were symptom free or had mild illness during seroconversion.

Six $(7 \%)$ patients developed AIDS, which was manifested as Pneumocystis carinii pneumonia in five and oesophageal candidiasis in one. All of the patients who developed AIDS had longlasting primary illnesses associated with seroconversion.

\section{Discussion}

This study found a significant relation between the course of the primary HIV infection and the long term outcome of the infection. The risk of developing AIDS related disease (Centers for Disease Control group IV) within three years of seroconversion was eight times higher for subjects with a longlasting acute illness during seroconversion than for those who were symptom free or had only mild symptoms during seroconversion $(78 \% v 10 \%)$.

This is the first report to describe an association between the severity of the primary infection and the subsequent course of the HIV infection. It is therefore crucial to consider if any factors may have biased this observation. Our study population was not chosen from a well defined cohort of subjects initially negative for HIV antibody, which means that subjects with symptoms related to HIV (primary illness or generalised lymphadenopathy) probably made up a fairly large proportion of the group. As all participants were in Centers for Disease Control groups I-III at entry, and as information about primary symptoms was obtained near the time of seroconversion, the comparison of clinical outcome in subjects with or without a symptomatic primary illness was not biased by our study design.

A longlasting primary illness was defined as an illness with a duration of at least 14 days. This time limit was chosen arbitrarily, but it must be emphasised that the relation between the severity of the primary illness and the subsequent risk of developing other symptoms related to HIV remained significant no matter what point between 0 and 14 days was chosen to distinguish between a longlasting and a mild primary illness (results not shown). This relation between the course of the primary HIV infection and the long term outcome of the infection indicates that the factors that determine the clinical response to the primary infection also determine the subsequent course of the infection.

During the initial phase of the infection many types of cells are infected, including monocytes, macrophages, microglial cells, and CD4 lymphocytes. The infection with HIV is persistent and life long, and it is believed that progressive disease is a consequence of a gradual rise in viral replication (from macrophages and monocytes) with a resultant increase in the number of latently infected CD4 lymphocytes, which on activation produce large amounts of virus and are subsequently killed. ${ }^{15}$ If this model for progressive disease is valid, both the kind of tissues infected and the number of cells infected during the initial phase may influence the subsequent course of the infection. Factors that could determine viral spread during the primary infection include the viral inoculum, the route of infection, the immune state of the person who is exposed, and the host response to the primary infection. A severe primary illness could reflect the elicitation of a vigorous humoral or cellular immune response, or both, directed against HIV and the resultant formation of antigen-antibody complexes and release of lymphokines. Such an activation of the immune system could create a fertile ground for HIV replication. ${ }^{15}$

Conversely, a severe primary illness could be related to an early and extensive spread of the virus owing to a defective host immune response. One of our patients was treated with prednisolone at the time of seroconversion and developed AIDS two months after seroconversion. This case, which has been reported elsewhere, ${ }^{16}$ and reports on disease progression in children, ${ }^{17}$ in elderly patients who received blood transfusions, ${ }^{\prime}$ and in people who were immunocompromised at exposure ${ }^{18}$ indicate that immune state may influence the subsequent outcome of the HIV infection.

The primary infection with HIV has been reported to occur both symptomatically ${ }^{19-21}$ and asymptomatically. ${ }^{22}$ In our study $46(53 \%)$ subjects reported an acute illness during the interval between negative and positive results on tests for HIV antibody. This high incidence of clinical illness associated with seroconversion is in accordance with an Australian and a Dutch series ${ }^{2124}$ but not with series from the United Kingdom and Canada. ${ }^{22}{ }^{23}$ We may have overestimated the incidence as patients with an acute disease may have been more likely to seek medical advice. On the other hand, their failure to recall trivial symptoms may have resulted in underreporting of mild primary illnesses. In contrast with other series, a fairly large proportion of our subjects who became positive for HIV antibody had clinical signs of immune deficiency such as oral thrush and oesophageal candidiasis. ${ }^{25}$ These manifestations were not persistent and probably reflect a transient immune suppression, as is seen on infection by other lymphocytopathic viruses. ${ }^{26}$

At three years of follow up over half the subjects had developed immune deficiency (defined as CD4 lymphocyte count $<0.5 \times 10^{\circ} / 1$ ), and more than a quarter had recurrence of HIV antigenaemia. Although HIV infection may persist for years with minimal or no symptoms, this early depletion of CD4 lymphocytes and the recurrence of HIV antigenaemia indicate that for a considerable proportion of those infected the disease is already active early in the chronic infection. This might have implications for starting antiviral treatment.

In conclusion, we found a strong association between a longlasting symptomatic primary HIV infection and the subsequent risk of developing other symptoms related to HIV. Future studies should focus on the pathogenesis of acute HIV infection as a delineation of the crucial early events may provide the basis for a better understanding of progressive immunodeficiency during HIV infection.

This study was supported by grants from the Michaelsen Foundation and the Danish Medical Research Council.

1 Medley GF, Anderson RM, Cox DR, Billard L. Incubation period of AIDS in patients infected via blood transfusion. Nature 1987;328:719-21.

2 Moss AR, Bacchetti F, Osmond D, et al. Seropositivity for HIV and the development of AIDS or AIDS related condition: three vear follow up of the San Francisco General Hospital cohort. Br Med F 1988;296:745-50.

3 Goedert JJ, Biggar RJ, Melbye M, et al. Effect of T4 count and cofactors on the incidence of AIDS in homosexual men infected with human immunodeficiency virus. JAMA 1987;257:331-4.

4 Polk BF, Fox R, Brookmeyer R, et al. Predictors of the acquired immunodeficiency syndrome developing in a cohort of seropositive homosexual men. $N$ Engl f Med 1987;316:61-6.

5 Hofmann B, Lindhardt B $\emptyset$, Gerstoft $\mathrm{J}$, et al. The lymphocyte transformation response to PWM as a highly predictive parameter for the development of AIDS and AIDS-related symptoms in homosexual men with antibodies to HIV. Br Med f 1987;295:293-6.

6 Pedersen C, Nielsen CM, Vestergaard BF, Gerstoft J, Krogsgaard K, Nielsen JO. Temporal relation of antigenaemia and loss of antibodies to core
antigens to development of clinical disease in HIV infection. Br Med 1987 ; 295:567-9.

7 Robert-Guroff $M$, Goedert JJ, Naugle CJ, Jennings AM, Blattner WA, Gallo RC. Spectrum of HIV-1 neutralising antibodies in a cohort of homosexual RC. Spectrum of HIV-1 neutralising antibodies in a cohort of homosexual men: results of a 6 year prospective study. AIDS Res Hum Retroviruses $1988 ; 4: 343-50$

8 Pedersen C, Kolby P, Sindrup JH, et al. Immunological studies in homosexual men with and without antibodies to human T-cell lymphotropic virus type III. Dan Med Bull 1986;33:270-2

9 Kolby P, Pedersen C, Sindrup JH, et al. The LAV/HTLV III screening in Copenhagen. Dan Med Bull 1986;33:267-72.

10 Lindhardt BO, Ulrich K, Ryder L, et al. HTLV-III testing in three Danish blood banks. V'ox Sung 1986;51(suppl : 9-13. 
11 Allain JP, Paul DA, Laurian Y, Senn D. Serological markers in early stages of human immunodeficiency virus infection in haemophiliacs. Lancet 1986;ii: 1233-6.

12 Centers for Disease Control. Classification system for human T-lymphotropic virus type IL/lymphadenopathy-associated virus infections. Ann Intern Med 1986;105:234-7.

13 Centers for Disease Control. Revision of the case definition of acquired immunodeficiency syndrome for national reporting. $M M W R$ 1985;34: $374-5$.

14 Peto K, Pike MC, Armitage DR, et al. Design and analysis of randomized clinical trials requiring prolonged observation of each patient. II. Analysis and examples. Br f Cancer 1977;35:1-39.

15 Haseltine WA. Replication and pathogenesis of the AIDS virus. Fourmal of AIDS 1988;1:217-40.

16 Pedersen C, Nielsen JO, Dickmeiss E, Jordal R. Early progression to the acquired immunodeficiency syndrome following primary human immunodeficiency virus infection. AIDS (in press)

17 Scott GB, Buck BE, Leterman JG, Bloom FL, Parks WP. Acquired immunodeficiency syndrome in infants. $N$ Engl J Med 1984:310:76-81.

18 Anderson KC, Gorgone BC, Marlink RG, et al. Transfusion-acquired human immunodeficiency virus infection among immunocompromised persons. Ann Intern Med 1986;105:519-27.
19 Cooper DA, Gold J, Maclean P, et al. Acute AIDS retrovirus infection. Lancet 1985;i:537-40.

20 Ho DD, Sarngadharan MG, Resnick L, Dimaszo-Veronese R, Rota TR, Hirsch MS. Primary human T-lymphotropic virus type III infection. Ann Intern Med 1985;103:880-3.

21 Tindall B, Barker S, Donovan B, et al. Characterization of the acute clinical illness associated with human immunodeficiency virus infection. Arch Intern Med 1988;148:945-9.

22 Weber JN, Rogers LA, Scott K, et al. Three-year prospective study of HTLV III infection in homosexual men. Lancet 1986; ; 1179-82.

23 Boyko WJ, Schenchter MT, Craib KJP, et al. The Vancouver lymphadenopathy-AIDS study: 7. Clinical and laboratory features of 87 cases of primary HIV infection. CMAf 1987;137:109-13.

24 Lange JMA, Parry JV, de Wolf F, Mortimer PP, Goudsmit J. Diagnostic value of specific IgM antibodies in primary HIV infection. AIDS 1988;2:31-5.

25 Pedersen C, Gerstoft J, Lindhardt B $\emptyset$, Sindrup J. Candida esophagitis associated with acute human immunodeficiency virus infection. F Infect Dis 1987; 156:529-30.

26 Rouse BT, Horohov DW. Immunosuppression in viral infections. Rev Infect Dis 1986;8:850-73.

(Accepted 12 April 1989)

\section{Poor response to treatment of renal anaemia with erythropoietin corrected by iron given intravenously}

\section{Iain C Macdougall, R David Hutton, Ivor Cavill, Gerald A Coles, John D Williams}

Institute of Nephrology, Cardiff Royal Infirmary, Cardiff CF2 1SZ Iain C Macdougall, MRCP, clinical research fellow Gerald A Coles, MRCP, consultant physician John D Williams, FRCP, senior lecturer

\section{Department of}

Haematology,

University of Wales

College of Medicine, Cardiff

R David Hutton, MRCPATH, senior lecturer

Ivor Cavill, FRCPATH, senior lecturer

Correspondence to: $\mathrm{Dr}$ Macdougall.

BrMed f 1989;299:157-8
Recombinant human erythropoietin is being used increasingly to treat renal anaemia in patients receiving haemodialysis and continuous ambulatory peritoneal dialysis. Its efficacy is undisputed; nevertheless, several centres have reported that some patients have responded poorly, slowly, or not at all. We report on five patients who responded poorly to such treatment until they were given iron intravenously.

\section{Case reports}

The five patients we describe participated in a study assessing the effect of erythropoietin on renal anaemia in 11 patients who were receiving regular haemodialysis. All five were treated with erythropoietin (Boehringer Mannheim) $240 \mathrm{U} / \mathrm{kg} /$ week intravenously and started prophylactic oral iron supplementation (ferrous gluconate $300 \mathrm{mg} /$ day; $35 \mathrm{mg}$ elemental iron) two weeks before the treatment with erythropoietin. Each patient had a normal serum ferritin concentration before treatment $(51,40,44,34$, and $37 \mu \mathrm{g} / 1$; normal range $15-300 \mu \mathrm{g} / \mathrm{l})$. Serum iron concentration and total iron binding capacity were monitored and the percentage saturation with transferrin calculated (serum iron concentration $(\mu \mathrm{mol} / \mathrm{l}) \div$ total iron binding capacity $(\mu \mathrm{mol} / \mathrm{l}) \times 100 \%)$.

The mean (SD) increase in haemoglobin concentration in the five patients was $25(13) \mathrm{g} / \mathrm{l}$ over the first eight weeks of treatment with erythropoietin compared with $45(20) \mathrm{g} / \mathrm{l}$ in six other patients in the study (all of whom had serum ferritin concentrations $>400$ $\mu \mathrm{g} / \mathrm{l}$ and transferrin saturations $>30 \%$ before treatment). Each of the five patients had an initial rise in haemoglobin concentration, which was not sustained; they were then given iron dextran intravenously (Imferon; $50 \mathrm{mg}$ elemental iron/ml) $1 \mathrm{ml}$ twice weekly during the last hour of dialysis.

The mean weekly rise in haemoglobin concentration during the four weeks before intravenous treatment with iron was $2.0 \mathrm{~g} / \mathrm{l}$; this rose to $5.3 \mathrm{~g} / \mathrm{l}$ after the treatment was started ( $p<0.005$, paired $t$ test), indicating more effective erythropoiesis even though the dose of erythropoietin was the same (table). Four of the patients had normal serum ferritin concentrations immediately before treatment with iron, suggesting adequate stores of iron in marrow; the remaining patient had a concentration at the lower limit of the normal range. In contrast, all five patients had low transferrin saturations $(<20 \%)$

\section{Comment}

Our data show a retarded response of haemoglobin concentration to erythropoietin, which was corrected by giving iron intravenously. Eschbach et al also reported on a patient in whom the response of the packed cell volume declined in the presence of an ample serum ferritin concentration $(518 \mu \mathrm{g} / \mathrm{l})$ but low transferrin saturation (13\%); this patient also responded to intravenous treatment with iron dextran. ${ }^{1}$

Erythropoietin seems to stimulate erythropoiesis to such an extent that the demand for iron can exceed the body's ability to release it from stores. This may lead to a functional iron deficiency, which can occur when serum ferritin concentrations are normal and iron can be detected in the marrow by staining.

Previous studies have suggested that stores of iron are adequate for erythropoiesis only if for every $50 \mathrm{~g} / \mathrm{l}$ rise in haemoglobin concentration a serum ferritin concentration of $\geqslant 100 \mu \mathrm{g} / \mathrm{l}$ is present. ${ }^{2}$ Patients who are particularly likely to develop functional iron deficiency, therefore, are those with serum ferritin

Clinical measurements in five patients receiving dialysis and treatment with erythropoietin before and after intravenous treatment with iron. Figures in parentheses are percentage transferrin saturations

\begin{tabular}{|c|c|c|c|c|c|c|c|c|c|}
\hline \multirow[b]{2}{*}{$\begin{array}{l}\text { Case } \\
\text { No }\end{array}$} & \multirow[b]{2}{*}{$\begin{array}{c}\text { Age } \\
\text { (years) }\end{array}$} & \multirow[b]{2}{*}{ Sex } & \multirow{2}{*}{$\begin{array}{l}\text { No of weeks of } \\
\text { treatment with } \\
\text { erythropoietin } \\
\text { when response } \\
\text { was poor }\end{array}$} & \multicolumn{3}{|c|}{ Before intravenous treatment with iron } & \multicolumn{3}{|c|}{ After intravenous treatment with iron } \\
\hline & & & & $\begin{array}{l}\text { Weekly increase } \\
\text { in haemoglobin } \\
\qquad(\mathrm{g} /)^{\star}\end{array}$ & $\begin{array}{l}\text { Serum } \\
\text { ferritin } \\
(\mu \mathrm{g} / \mathrm{l}) \dagger\end{array}$ & $\begin{array}{c}\text { Serum iron }(\mu \mathrm{mol} / \mathrm{l}) / \\
\text { total iron binding capacity } \\
(\mu \mathrm{mol} / \mathrm{l}) \dagger\end{array}$ & $\begin{array}{c}\text { Weekly increase } \\
\text { in haemoglobin } \\
(\mathrm{g} / \mathrm{l}) \mp\end{array}$ & $\begin{array}{l}\text { Serum } \\
\text { ferritin } \\
(\mu \mathrm{g} / \mathrm{l}) \S\end{array}$ & $\begin{array}{c}\text { Serum iron }(\mu \mathrm{mol} / \mathrm{l}) / \\
\text { total iron binding capacity } \\
(\mu \mathrm{mol} / \mathrm{l}) \oint\end{array}$ \\
\hline $\begin{array}{l}1 \\
2 \\
3 \\
4 \\
5\end{array}$ & $\begin{array}{l}26 \\
51 \\
22 \\
53 \\
52\end{array}$ & $\begin{array}{l}M \\
F \\
M \\
M \\
M\end{array}$ & $\begin{array}{l}5-7 \\
4-8 \\
2-6 \\
3-6 \\
2-6\end{array}$ & $\begin{array}{l}2 \cdot 3 \\
1 \cdot 8 \\
0 \cdot 3 \\
2 \cdot 3 \\
3 \cdot 3\end{array}$ & $\begin{array}{l}16 \\
35 \\
32 \\
14 \\
31\end{array}$ & $\begin{array}{l}4 \cdot 8 / 54 \cdot 0(8 \cdot 9) \\
5 \cdot 0 / 57 \cdot 5(8 \cdot 7) \\
7 \cdot 8 / 44 \cdot 4(17 \cdot 6) \\
6 \cdot 7 / 54 \cdot 0(12 \cdot 4) \\
8 \cdot 5 / 50 \cdot 6(16 \cdot 8)\end{array}$ & $\begin{array}{l}8 \cdot 0 \\
3 \cdot 5 \\
3 \cdot 8 \\
4 \cdot 8 \\
6 \cdot 3\end{array}$ & $\begin{array}{l}17 \\
56 \\
21 \\
30 \\
16\end{array}$ & $\begin{array}{l}23 \cdot 2 / 59 \cdot 8(38 \cdot 8) \\
20 \cdot 0 / 53 \cdot 3(37 \cdot 5) \\
47 \cdot 0 / 53 \cdot 3(88 \cdot 2) \\
17 \cdot 5 / 56 \cdot 5(31 \cdot 0) \\
14 \cdot 0 / 57 \cdot 2(24 \cdot 5)\end{array}$ \\
\hline
\end{tabular}

